\section{Energy} Economics

Energy Economics 30 (2008) 2552-2568

\title{
Measuring the importance of oil-related revenues in total fiscal income for Mexico
}

\author{
Manuel Lorenzo Reyes-Loya, Lorenzo Blanco* \\ Facultad de Economía, Universidad Autónoma de Nuevo León, Loma Redonda \#1515 Pte., \\ Col. Loma Larga, C.P. 64710, Monterrey, Nuevo León, Mexico
}

Received 28 February 2007; received in revised form 8 February 2008; accepted 9 February 2008

Available online 20 February 2008

\begin{abstract}
Revenues from oil exports are an important part of government budgets in Mexico. A time-series analysis is conducted using monthly data from 1990 to 2005 examining three different specifications to determine how international oil price fluctuations and government income generated from oil exports influence fiscal policy in Mexico. The behavior of government spending and taxation is consistent with the spend-tax hypothesis. The results show that there is an inverse relationship between oil-related revenues and tax revenue from non-oil sources. Fiscal policy reform is urgently needed in order to improve tax collection as oil reserves in Mexico become more and more depleted.

(C) 2008 Elsevier B.V. All rights reserved.
\end{abstract}

JEL classification: O13; O54; Q32; Q48

Keywords: Fiscal policy; Mexico; Oil price fluctuations; Unexpected oil revenues

\section{Introduction}

Given its location and climate, Mexico is endowed with a wide variety of natural resources. Oil is one of the resources that has played an important role in both the economic and the political development of Mexico (Everhart and Duval-Hernandez, 2001; Morales et al., 1988). The Mexican government classifies its revenues from oil exports as part of its fiscal income. About one-third of the total fiscal income in Mexico is generated from oil exports (see Fig. 1). This has

* Corresponding author. Tel.: +52 818329 4150; fax: +52 8183422897.

E-mail address: lorenzoblanco2000@yahoo.com (L. Blanco). 


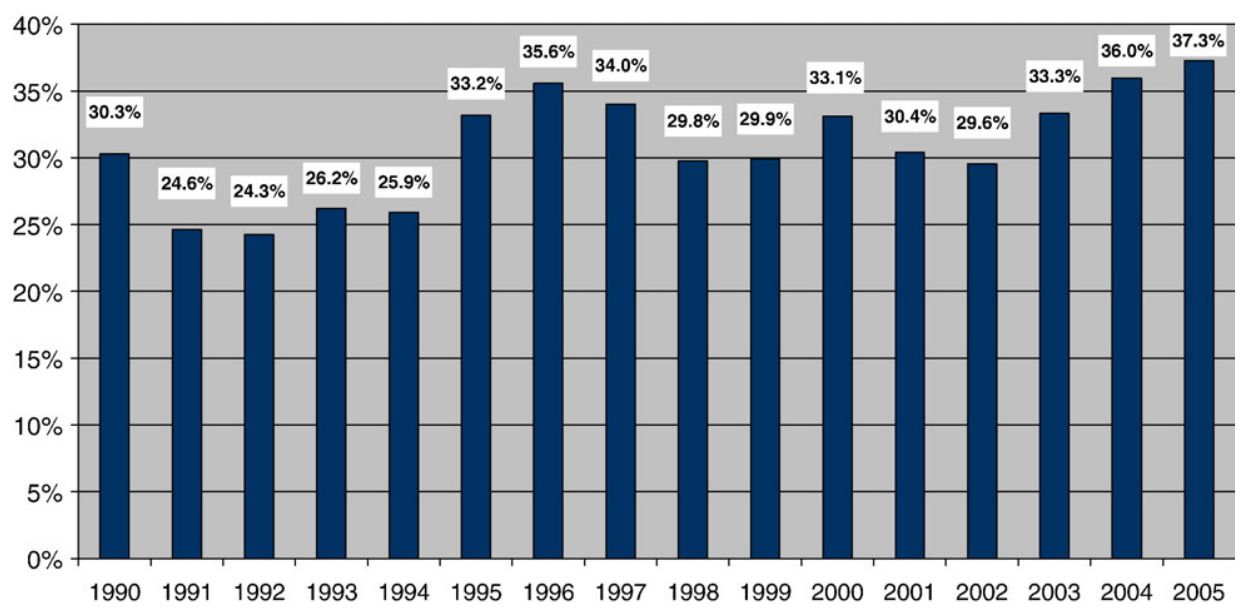

Fig. 1. Petroleum income participation as a percentage of total fiscal income. Source: Own elaboration based on data provided by Secretaria de Hacienda y Credito Publico.

caused the nation's budget to become "petrolized," or extremely dependent on oil and its derivatives (Everhart and Duval-Hernandez, 2001).

This paper measures the impact of oil exports as a key factor in fiscal policy. To do so, a timeseries analysis is conducted using monthly data from 1990 to 2005 examining three different specifications to determine how international oil price fluctuations and government income generated from the oil exports influence fiscal policy in Mexico. An inverse relationship is expected between oil income and non-oil taxation.

The excessive reliance on oil revenues in Mexico and the hypothesized inverse relationship between oil and non-oil tax revenues, as a percentage of total government revenue, have important policy implications. If the taxation scheme for Mexico's state-owned petroleum company were changed, then the fiscal structure in the country would change. The government would have the incentive to expand its tributary base and develop better tax collection schemes. The role of oil in the Mexican economy would change from being a source of government revenue to an engine of growth.

\section{Background}

Oil industry analysts make a distinction between proven and probable reserves. Proven reserves are those currently being exploited, as well as those exploited within the past 5 years that are expected to be exploited again in the future (Shields, 2003). Probable reserves have been discovered but are not being exploited because either economic or technical reasons (Shields, 2003). Mexico is a well-recognized oil exporter with about 14 billion barrels of proven reserves and about 12 billion barrels of probable reserves (Karl, 1999; Morales et al., 1988; Secretaría de Energía [SENER], 2004). There is some evidence of additional possible reserves in the Gulf of Mexico $^{1}$. However, Shields (2003) claims that these reserves cannot be exploited immediately because of the lack of deep-sea oil extraction technology in Mexico. Fernando de Jesús Canales

\footnotetext{
${ }^{1}$ About 8 billion barrels are calculated for Mexico. Possible reserves are based on ground statistical studies (i.e. deep sea oil in the Gulf of Mexico). (Secretaría de Energía [SENER], 2004).
} 
Clariond, Secretary of Energy in Mexico (2005-2006), supported this statement during an interview for a television broadcast (Padilla, 2005).

The total amount of Mexican proven reserves has declined considerably during the last 15 years. Between 1990 and 2004, proven reserves declined 24\% with an average annual decrease of $1.91 \%$. The reason for this substantial decrease is the lack of investment in oilfield exploration and exploitation of new oilfields (SENER, 2004). Under the current exploitation rate, Mexico's proven reserves are forecasted to last only until 2016. However, Mexico will run out of oil sooner than predicted if proven reserves continue to be overexploited ${ }^{2}$ and if new oilfields ${ }^{3}$ are not discovered in the near future (Shields, 2003).

Mexico has three different types of oil: Maya (heavy), Istmo (light), and Olmeca (ultra light). Oil is classified based upon its density; ${ }^{4}$ the lower the density, the more profitable the exploitation. Depending on the production and sales of the three types of oil, a weighted mixed price is developed, known as Mexican Oil Mix or Mezcla Mexicana de Petróleo (MMP). Mexican production is currently about 72\% Maya, 15\% Istmo, and 13\% Olmeca (SENER, 2004). Most Maya oil is produced in the largest oilfield in Mexico: Canterell, discovered off the coast of the state of Campeche during the administration of President José López Portillo (1976-1982). This super-giant oilfield yields more than $60 \%$ of total national crude oil production. However, the total output of this oilfield has been declining since 2003 as a result of its natural maturity process (Shields, 2003).

Mexico's dependence on oil has been an important issue since super-giant oilfields such as Canterell were found in 1977 and 1978 (Morales et al., 1988). More than half of the total production of crude oil in Mexico (1860.3 mbd) in 2003 was exported, and about $80 \%$ of export total sales were to the United States (SENER, 2004; Shields, 2003). Since 1985, the Mexican government has focused on diversifying total exports. Non-oil exports were encouraged and stimulated by former presidents Carlos Salinas de Gortari (1988-1994) and Ernesto Zedillo Ponce de León (1994-2000) $)^{5}$ (Lustig, 1998). Therefore, as shown in Fig. 2, oil exports as a percentage of total exports have decreased progressively (Lustig, 1998).

\section{PEMEX and the Mexican government}

According to Article 27 of the Mexican Constitution, the Mexican nation owns oil and its derivatives (Shields, 2003). Petróleos Mexicanos (PEMEX) is the state-owned enterprise with the exclusive privilege to explore, exploit, transport, refine, and process Mexican crude oil or any other oil derivative in Mexico. The constitutional prohibition on foreign investment, as well as a daunting tax load hampers the growth of this state-owned enterprise (Padilla, 2005). Because it lacks resources to develop its own oil industry, PEMEX must subcontract or outsource some functions to privately owned companies. However, such companies are not always willing to provide their services under PEMEX's constitutional restrictions. Mexico's Energy Secretary from 2005 to 2006, Fernando de Jesus Canales Clariond, has argued that the low and limited profits available to companies contracting with PEMEX are not that attractive.

\footnotetext{
2 The regular exploitation rate in Mexico has been recently increased to meet the needs of the United States of America, due to its political differences with the Middle East and Venezuela.

${ }^{3}$ New oilfields usually take 6 to 10 years of exploration to be discovered.

4 The oil densities are: extra heavy, heavy, medium, light and ultra light.

5 These two presidents focused on trade liberalization. This helped diversify exports and reduce oil exports as a percentage of total exports.
} 


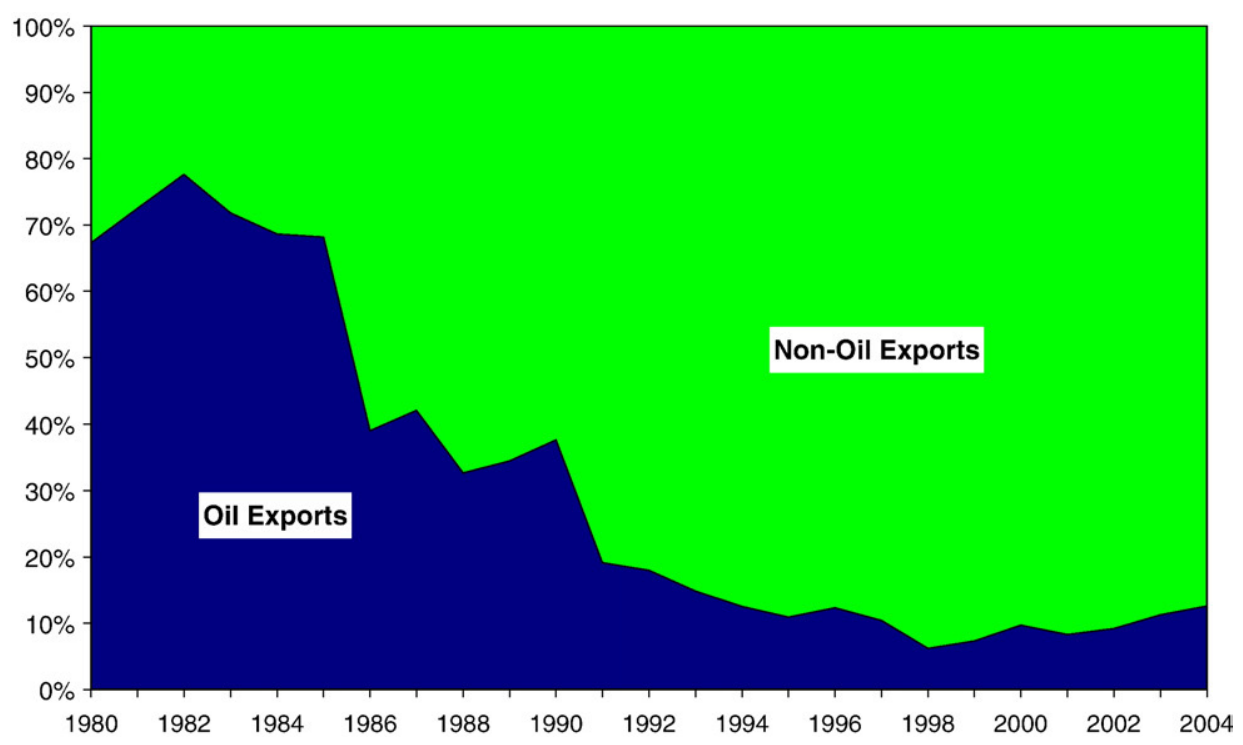

Fig. 2. Oil exports as a percentage of total exports. Source: Own elaboration based on data provided by Instituto Nacional de Estadistica, Geografia e Informatica.

According to Shields (2003), a ranking published by Petroleum Intelligence Weekly (PIW) based on oil production and proven reserves available in 2001 named PEMEX the seventh most important company in the world oil sector (see Table 1). During the same year, PEMEX was also one of the three largest oil producers on a daily basis. However, the first and second largest producers have much more proven reserves than Mexico: Saudi Arabia has 1200\% more, and Iran has $400 \%$ more. Compared to the average production of oil-exporting countries, Mexico has an unplanned excessive production, which in the long run will lead to an early exhaustion of Mexican reserves (Shields, 2003).

Table 1

The most important oil companies

\begin{tabular}{lllll}
\hline Company & Property of & Production & Revenues & Employee \\
\hline 1. Saudi Aramco & State-owned & 8301 & N/A & 54,077 \\
2. Exxon Mobil & Private & 2542 & 191,201 & 97,900 \\
3. Petroleos de Venezuela & State-owned & 3000 & 46,250 & 46,425 \\
4. NIOC (Iran) & State-owned & 3773 & N/A & 114,602 \\
5. Royal Dutch/Shell & Private & 2220 & 138,252 & 91,000 \\
6. BP Amoco & Private & 1931 & 176,551 & 110,150 \\
7. Petroleos Mexicanos & State-owned & 3560 & 39,617 & 134,852 \\
8. Chevron Texaco & Private & 1959 & 99,699 & 67,569 \\
9. Total Fina Elf & Private & 1454 & 95,677 & 122,025 \\
10. PetroChina & State-owned (90\%) & 2092 & 28,903 & 422,554 \\
\hline
\end{tabular}

Source: Petroleum Intelligence Weekly 2002.

Notes:

**Liquid hydrocarbons in thousand barrels per day.

$* * *$ In million of USD. 
In 2001, Mexico was the fourth largest exporter of crude oil among nations, and PEMEX was the third largest exporter of petroleum among companies worldwide. In the same year, PEMEX had the seventh largest revenue in the world among oil companies, and its operating income was greater than that of Exxon Mobil and BP Amoco. Even so, PEMEX reported a net loss during 2001 (Shields, 2003). Shields (2003) uses the PIW statistical report to show the "absurd situation" PEMEX experienced during that year (p. 41). PEMEX's gross revenue was \$39.62 billion USD, but it paid fees, taxes, and yields (detailed below) equal to $\$ 43.35$ billion USD during 2001. As a result of the brutal tax load charged by the Mexican government, PEMEX needed to borrow $\$ 3.73$ billion USD to meet its fiscal obligations (Shields, 2003).

Because of Mexico's tax structure, which is historically inefficient in collecting sufficient revenue through other means (such as individual labor earnings), PEMEX must supply an inordinate percentage of the nation's fiscal income. As a direct result, the company lacks sufficient resources to invest in technological improvements, expansion, or even proper maintenance. The government usually retains most of PEMEX's revenue instead of taxing its operating income like other companies (Tijerina-Guajardo and Pagán, 2003; Shields, 2003). Fiscal contributions from PEMEX comprise a wide array of taxes and fees. The total amount of all these contributions is adjusted to excise $60.8 \%$ of total oil revenues. Therefore, PEMEX always gets $39.2 \%$ of its gross revenue by law (Servicio de Administracion Tributaria [SAT], 2005). See Fig. 3.

PEMEX's fiscal obligations are complex (see Table 2). In terms of taxes, PEMEX pays the traditional value-added tax (IVA) for various production stages. The rate depends on location: It is $10 \%$ along the border and 15\% in Mexico's interior. PEMEX also pays a special tax on goods and services (IEPS) of $86.96 \%$ to $90.91 \%$. This tax is effectively a cost of goods sold, paid by the franchisee of gasoline or other petroleum products. The rate varies depending on the sales tax zone.

PEMEX also pays a long list of fees, known as derechos in Mexican legislation. Table 2 lists seven of these fees, two of which charge a percentage over other fees. In other words, PEMEX actually pays additional or "extraordinary" fees over fees. In addition, PEMEX pays yields or aprovechamientos, defined as neither taxes nor fees in Article 3 of the fiscal code $(H$. Congreso de la Unión, 2006). PEMEX pays these yields based on $30 \%$ of its revenues minus fiscal deductions.

\section{PEMEX's TAX Structure}

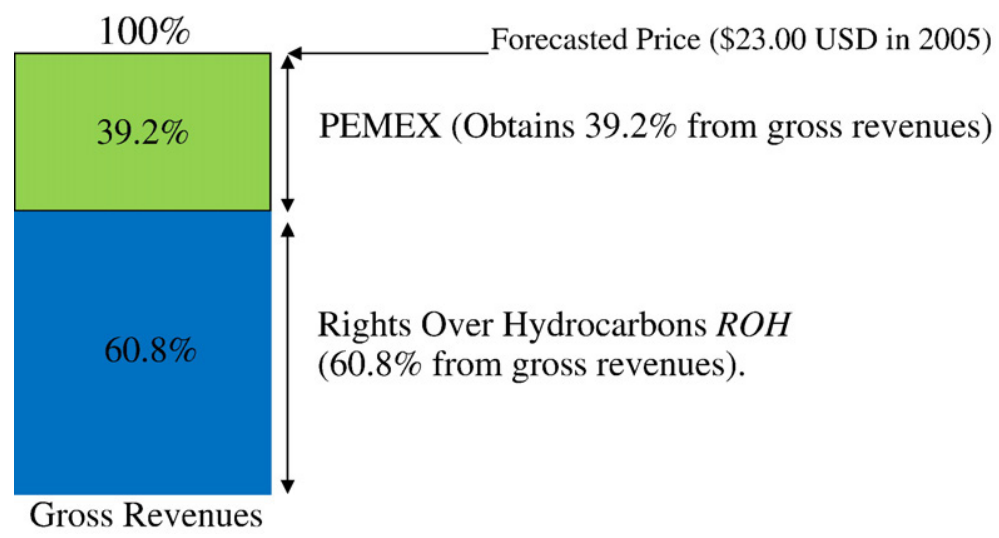

Fig. 3. PEMEX's Tax Structure I. Source: Own elaboration based on Mexican Legislature. 
Table 2

Tax burden for PEMEX

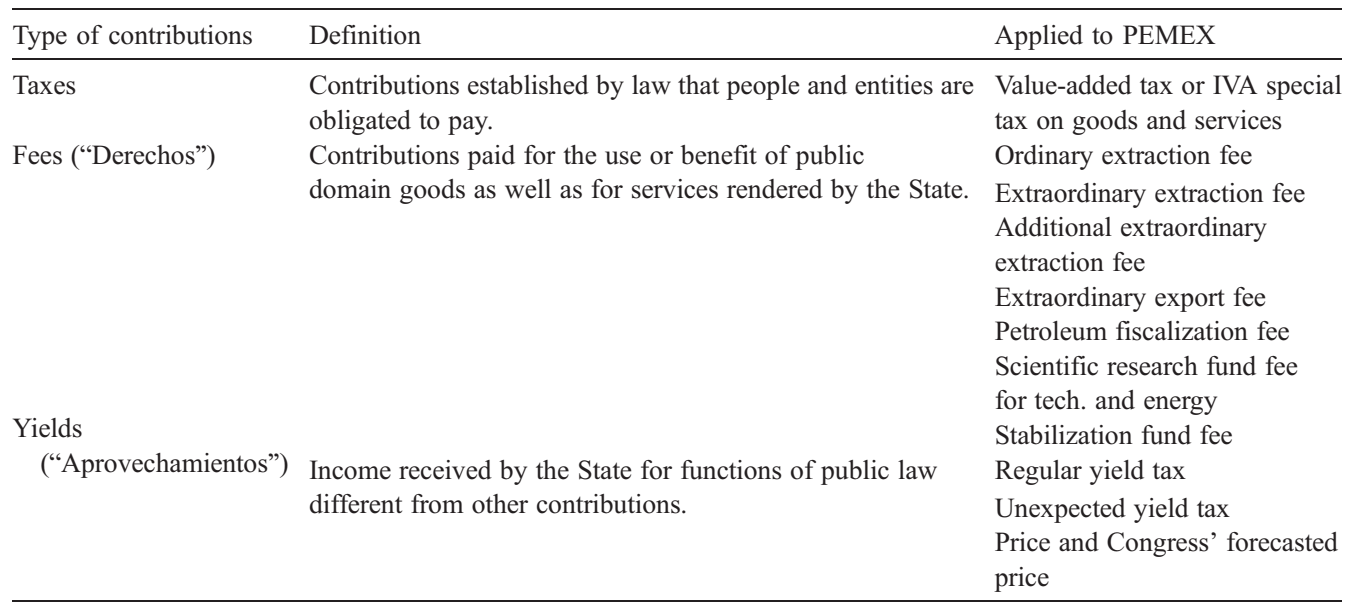

Source: Heroico Congreso de la Unión. Ley de Ingresos de la Federación (2005) and Codigo Fiscal de la Federación (2006).

In December of each year, the Mexican Congress estimates an average weighted price (MMP) for the following year (Heroico Congreso de la Unión, 2006). This average is used to estimate the federal government's budget and expenditures. Based on this forecast, an estimate of gross oil revenues is computed.

In December of 2004, Congress forecasted the price of oil to be $\$ 23.00$ USD per barrel for the following year. On July 5, 2005, the actual price was $\$ 46.02$ USD. This should have been good news for PEMEX. Ironically, as Fig. 4 demonstrates, this considerable price increase did not benefit the state-owned enterprise at all.

In cases like this, the federal government charges PEMEX as follows. It initially levies contributions over the $60.8 \%$ of gross revenues based on the forecasted price, $\$ 23.00$ USD $(30.4 \%$ based on $\$ 46.02$ USD). Then the government charges PEMEX again, over the $60.8 \%$ of excess gross revenues (another $30.4 \%$ based on the actual price). In other words, the government manages to get

\section{PEMEX's TAX Structure}

Real Price (\$46.02 USD In 07/05/2005)
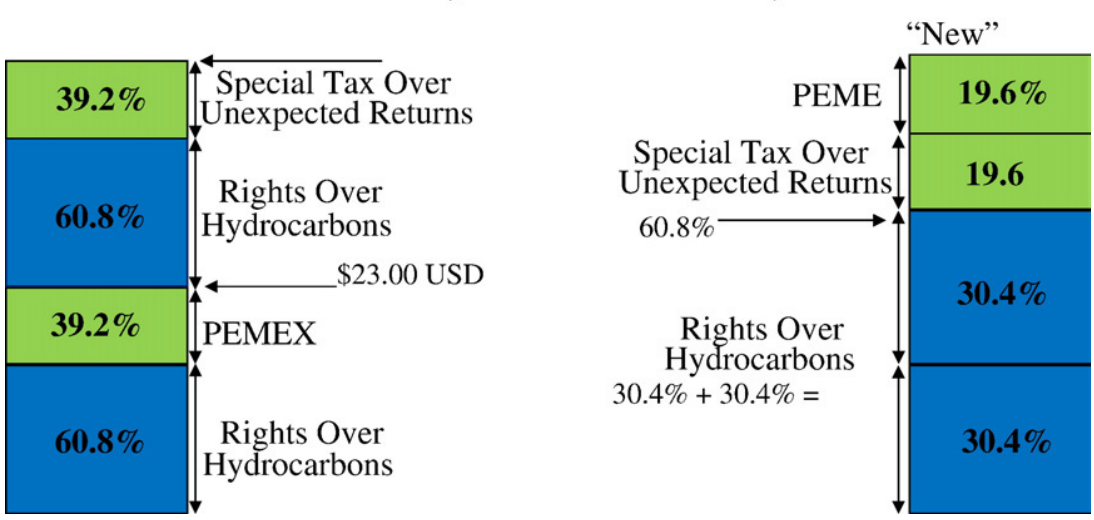

Fig. 4. PEMEX's Tax Structure II. Source: Own elaboration based on Mexican Legislature. 
$60.8 \%$ of the revenues generated by the actual price $(30.4 \%$ plus $30.4 \%$ of gross revenues from $\$ 46.02$ USD). PEMEX retains only $39.2 \%$ of gross revenues based on the forecasted price. In other words, it keeps only $19.6 \%$ of actual gross revenues. The government levies the other $19.6 \%$ as "unexpected yields."

In the end, PEMEX does not benefit from increases in oil prices. If the actual price exceeds Congress' estimations, which is frequently the case, the government seizes $100 \%$ of the excess amount (SAT, 2005; Shields, 2003).

\section{The apparent paradox of oil abundance}

Extensive research has been conducted analyzing the relation between natural resource abundance and economic growth. A positive impact on the economy is predicted in classical economic theory, when natural resources are abundant (Kronenberg, 2004). In fact, natural resources are classified as one of the ten most robust variables in empirical studies on economic growth (Doppelhofer et al., 2000; Sala-i-Martin, 1997). On the other hand, numerous researchers, for example Gylfason (2001), Sachs and Warner (1995), and Sala-i-Martin (1997), have found a significant negative correlation between natural resource abundance and economic growth.

According to Kronenberg (2004), empirical studies show that today most of the richest countries, are poorly endowed with natural resources. (The United States and Canada are important exceptions.) For instance, most resource-poor countries in Western Europe have based their economies on manufacturing and services. And during the second half of the twentieth century, the so-called Asian "tigers" - none of which are endowed with abundant natural resources - have shown higher growth rates than any other country in the world.

This "apparent paradox" of natural resources (Kronenberg, 2004, p. 400) is also found in crosscountry studies. Sachs and Warner (1995) look at economic growth and natural resource endowments from 1970 to 1989 . They find a significant negative correlation between natural resource exports as a fraction of GDP and GDP growth (Sachs and Warner 1995, 2001). Gylfason (2001) finds a negative relationship between economic growth and the share of natural capital in total capital. Kronenberg (2004) analyzes a sample of 26 developing countries in Eastern Europe and finds strong evidence that suggests that natural resource abundance is associated with slow economic growth. Sachs and Warner (2001) find that "almost without exception the resourceabundant countries have stagnated in economic growth since the early 1970s" (p. 837). They conclude that the negative correlation between natural resources and growth is not easily explained by other variables. Sachs and Warner (2001) also explore omitted variables such as geography and climate, as well as bias resulting from some other unobserved growth deterrent, but neither one provides strong evidence to justify the economic stagnation. Among others, these studies corroborate the notion that a large endowment of natural resources leads to slower economic growth in a country (Kronenberg, 2004).

However, being endowed with abundant natural resources is not de facto bad for an economy. Natural wealth is not the problem. The problem is that governments seldom "avert the dangers" that come from natural resource abundance (Gylfason, 2001, p. 851). Good policies are necessary for natural resource wealth to become "an unambiguous blessing" (Gylfason, 2001, p. 851).

Economic growth in the long run tends to be slower in most of the countries rich in minerals, oil, and other natural resources (Gylfason, 2001). Hausmann and Rigobon (2002) suggest that the main problems of oil dependence are associated with volatility in oil prices and exhaustibility of oil wealth. Oil revenues, in particular, are subject to shocks from price fluctuations. The windfalls from oil exploitation and sales may not be beneficial all the time (Gelb, 1988). 
Gelb (1988) analyzes oil windfalls in six exporting countries during the 1973 and 1979 oil booms, concluding that they are more of a curse than a blessing. In theory, any export boom could be transformed into sustained economic development. Governments, however, choose suboptimal economic policies and misuse these revenues (Gelb, 1988; Morales et al., 1988; Street, 1985). Oil-rich countries may actually perform better without the windfalls (Gelb, 1988).

Kronenberg (2004), for example, finds that Azerbaijan is a good example of overall economic growth not necessarily stimulated by fast-growing exports of fuels. On the other hand, Nigeria, an oil-wealthy nation, exhibited a per capita GNP in 2001 that was no higher than it was in 1960 (Gylfason, 2001). From 1965 to 1998, per capita GNP growth in several oil-producing nations was negative (Gylfason, 2001).

Roy and Van den Berg (2000) analyzed the potentiality of petroleum exports as an engine of growth. They conducted an empirical analysis based on trade and productivity. The oil and non-oil exports of five oil-exporting countries were tested as determinants of GDP growth in a time-series analysis. Neither Nigeria's nor Iran's exports of oil or non-oil were significantly related to economic growth. Mexico's non-oil exports proved to be more significantly related to real GDP growth than oil exports. Venezuela and Ecuador's oil exports were significantly and positively related to real GDP.

Natural resource abundance may create a false sense of security in people (Auty, 2001). The resource-rich countries' authorities become overconfident and tend to overlook the need for adjustments in economic or fiscal policies (Gylfason, 2001). Sometimes necessary and possibly painful reforms are delayed because natural resource exports alone provide the country with enough means to survive (Kronenberg, 2004). For example, Chalk (1988) has shown that oildependent countries can enjoy resource-related revenues that serve as a substitute for fiscal reform when the country's terms of trade are favorable. Moreover, Hamilton (2001) finds that many resource-abundant countries fail to invest the resource rents in productive assets like human capital and instead simply consume them. Indeed, resource-rich nations can live well from their natural resources over extended periods, even with poor economic policies (Gylfason, 2001).

Hausmann and Rigobon (2002) offer an alternative explanation for the inverse relationship between natural resources and growth. They develop a model relating low-growth performance with government spending, financial market deficiencies, and specialization in non-tradable goods. They conclude, based on empirical evidence, that the key to achieving welfare and macroeconomic performance is the reduction of the level and volatility of government expenditures.

Tijerina-Guajardo and Pagán (2003) support Hausmann and Rigobon's conclusion. They go further, stating that if a country is highly dependent on oil revenues to finance government spending, its economy is at the mercy of sudden changes in the market price of oil. Unanticipated reductions in oil revenues may cause fiscal imbalances and financial distress. Many things affect nations endowed with natural resources, and most of them are beyond the governments' control.

Adequate fiscal policy is clearly the key to turning natural resource abundance into long-term economic stability and growth (Lewin and Devlin, 2002). If fiscal imbalances or financial distress are present, corrective policies should be taken. However, before solving a problem, it needs to be observed or detected first. Hausmann and Rigobon (2002) recommend improving budget institutions, debt management, and policy credibility, as well as the enhancement of domestic financial markets. Devlin and Titman (2004) recommend the use of windfalls on stabilization and saving funds as an alternative to "turn depletable wealth into productive assets." However, they recognize the limited effectiveness of these measures when political factors and policymakers' personal interests surpass economic guidance.

Mexico is an oil-endowed nation that has faced difficulties in managing oil booms. After the discoveries of massive oil fields in 1977 and 1978, high rates of economic growth were expected; 
however, "the opportunity provided by oil revenues was largely overestimated, and the revenues misused" (Lustig, 1998, p. 20). Furthermore, future revenue expectations raised the fiscal deficit, in part financed by international commercial banks.

During José López Portillo's presidential administration (1978-1984), the expansionary policies followed by the Mexican government exacerbated the effects of a natural resource windfall, or "Dutch Disease" (Kronenberg, 2004, p. 414; Lustig, 1998). The abundance of natural resources increased aggregate demand, generating inflationary pressures in non-tradable goods and wages and consequently appreciating the exchange rate, thus stimulating imports (Kronenberg, 2004; Lustig, 1998; Street, 1985). Imports increased in Mexico, aggravating the trade deficit and increasing dependence on oil exports (Lustig, 1998).

Tijerina-Guajardo and Pagán (2003) find that there is a substitution effect between oil duties and tax revenues in Mexico. Mexico, like other oil-dependent countries, cannot compensate negative oil-price shocks with increases in tax revenues in the short run (Tijerina-Guajardo and Pagán, 2003). They also find evidence supporting the tax-spend hypothesis; in other words, tax revenues determine government spending (Friedman, 1978).

On the other hand, Crandall et al. (2005) partially contradict Tijerina-Guajardo and Pagán (2003) by asserting that short-term adjustments raise government revenue in the short run via the reduction of tax exemptions or tax increments on inelastic products. Furthermore, the empirical analysis below is consistent with the spend-tax hypothesis in which taxation adjusts to pre-targeted levels of government expenditure (Peacock and Wiseman, 1979; Barro, 1979; Baghestani and McNown, 1994).

What most researchers do agree upon is the relationship between non-oil tax revenues and the level of oil exports. This is consistent throughout the literature even though some cannot explain the exact mechanism that brings about this nexus (Boye, 2002). The empirical analysis below offers an explanation based on Mexico's gaping problem in collecting taxes.

\section{Data}

Data on government spending, fiscal policy, and oil-related revenues include 192 monthly observations from January 1990 to December 2005. This is the widest interval in which data for all of these variables are available. This information can be obtained directly from the official website of the Finance Ministry in Mexico (SHCP by its Spanish acronym). ${ }^{6}$

The National Statistics Institute (INEGI) publishes quarterly, not monthly, data on gross domestic product (GDP). It also publishes monthly data for the Industrial Production Index (IPI), used as a proxy for GDP in this study. This index is calculated using the four major divisions of economic activity in Mexico: Gas and Water, Manufacturing and Construction, Electricity, and Mining (Instituto Nacional de Estadistica Geografia e Informatica [INEGI], 2006). These data correspond with the 192 monthly observations described above and are available on the INEGI official website. ${ }^{7}$

The Mexican Petroleum Institute (IMP) provides data for the weighted Mexican price of oil (MMP), but this series lacks 14 months' worth of observations from January 1997 through March

\footnotetext{
${ }^{6}$ The website is www.shcp.gob.mx, and the data tables are located under "Estadísticas Oportunas de Finanzas Públicas y Deuda Pública" (Secretaría de Hacienda y Crédito Público [SHCP], 2006). (From the home page, first click on "Información Económica").

${ }^{7}$ The website is http://dgcnesyp.inegi.gob.mx, and the data are located under "Indicadores Internacionales." (From the home page, first click on "Banco de Información Económica").
} 
1998; no other institution could provide the complete series. However, price data on Maya, Istmo, and Olmeca petroleum are available for the entire series. Most of the oil produced in Mexico is Maya, and the correlation between its price and the MMP price is high. In fact, movements in the price of this type of petroleum explain $99.35 \%$ of MMP variance. Therefore, the price of Maya petroleum can be used in place of MMP. The series for both the Maya and MMP prices are available on the IMP official website. ${ }^{8}$ The data for the Maya variable correspond with the 192 monthly observations described above.

The Mexican Central Bank (Banxico) calculates the Consumer Price Index, and INEGI provides it on its website. ${ }^{9}$ This index is used to measure changes in Mexico's cost of living using the second half of June 2002 as the base year $(06 / 2002=100)$. In this study, this index is employed to deflate variables that are in current pesos, such as government spending, tax, and oil-related revenues.

The Energy Department (SENER) provides annual forecasted oil prices and the total number of petroleum barrels exported. ${ }^{10}$ Data on forecasted prices are available from 1994 to 2004. Because it is annual data, the same price is used for the 12 months of each year in the series. The number of barrels exported is available from January 1990 to December 2004 and is measured on an average daily basis. It is necessary to transform these data from daily to monthly figures by simply multiplying the quantities by the number of days in the corresponding months.

The Mexican Central Bank (Banxico) calculates the exchange rate, and INEGI provides it in its website. There are several types of exchange rates computed by Banxico. In this study, the average exchange rate for foreign obligations is used, mainly because it is used for similar calculations by other government agencies.

\section{Model}

There is no ex ante relationship between oil-related and tax revenues. However, "the curse" or "apparent paradox" mentioned above (Gylfason, 2001; Kronenberg, 2004; Sachs and Warner, 1995; Sala-i-Martin, 1997) suggests a country well-endowed with natural resources is likely to be inefficient when it comes to difficult policy measures. The model in this study measures the relationship between oil- and non-oil-related revenues collected through taxation for the Mexican government. It predicts that oil-related income has an important impact on the behavior of nonoil-related revenues.

Taxes in Mexico can be classified in six categories. Some of them are better known by their Spanish acronyms: oil-related, income (ISR), value-added (IVA), business (IEPS), import tariffs, and "others." 11 The last five categories can be considered non-oil-related revenues; they normally represent about $50 \%$ of total government revenue. Oil-related revenues represent about $30 \%$, state-owned enterprises (except for PEMEX) about 12\%, and other activities account for the remaining $8 \%$. Oil-related revenues compile ordinary taxes applied to PEMEX: exploration and exploitation rights, exporting licenses, special and extraordinary taxes, taxes on unexpected oil revenues, etc.

\footnotetext{
8 The website is www.imp.mx, and the data are located under "El Petróleo" (Instituto Mexicano del Petróleo [IMP], 2006).

9 The website is http://dgcnesyp.inegi.gob.mx, and the data are located under "Indicadores Internacionales." (From the home page, first click on "Banco de Información Económica").

${ }^{10}$ The Mexican Congress computes the annual forecast of next year's oil price in December. Data on oil prices are provided by SENER (Sistema de Información Energética [SIE], 2006) and are available upon request. The website is http://sie.energia. gob.mx, and the information on barrels exported is provided under the heading of crude oil, hydrocarbons. (From the home page, first click on "Entrar", then on "Información Estadística", and then on the "Hidrocarburos" folder).

${ }^{11}$ The tax on new automobiles (ISAN), for example, falls under this category.
} 
The sum of non-oil tax revenues is employed to represent fiscal policy taxation (FPT) in the model. In order to measure and evaluate current fiscal policy in Mexico, non-oil tax revenues are used as the dependent variable. The most important variable on the right hand side of the equation is the sum of oil-related revenues (ORR) obtained by the government. Thus, these two variables constitute the basis of the model:

$$
\mathrm{FPT}=\alpha+\beta_{1} \mathrm{ORR}+\varepsilon .
$$

Where $\alpha$ is the intercept of the equation and the error $\varepsilon$ is independently and identically distributed (i.i.d.) with zero mean.

However, there is a strong relationship between government revenues and expenditures. As mentioned above, the direction of causality between these variables is still debatable. But for the purposes of the present study, the spend-tax hypothesis is used. Therefore, the equation should include this variable:

$$
\mathrm{FPT}=\alpha+\beta_{1} \mathrm{ORR}+\beta_{2} \mathrm{GS}+\varepsilon .
$$

Where GS represents total expenditures by the Mexican government.

Although Eq. (2) provides a more complete approach to define FPT behavior, additional variables should be included. Omitting an important variable causes the equation to be misspecified and consequently biases the results (Wooldrigde, 1992). Gross domestic product (GDP) is clearly related with taxation; consequently, it is imperative to include it as well.

However, there are two reasons GDP cannot be included explicitly in the regression. First, government spending is a component of GDP, so including it in the regression causes multicollinearity. Second, GDP is not available on a monthly basis for Mexico. One alternative is the Industrial Production Index (IPI):

$$
\mathrm{FPT}=\alpha+\beta_{1} \mathrm{ORR}+\beta_{2} \mathrm{GS}+\beta_{3} \mathrm{IPI}+\varepsilon .
$$

The IPI is calculated based on physical units and is presented in percentage form (similar to the Consumer Price Index).

An alternative specification would substitute oil-related revenues (ORR) with the weighted mixed price in Mexico (MMP) in order to incorporate international oil price fluctuations. While ORR gives total oil-related revenue, the use of MMP in the model gauges variation in oil price. However, as mentioned before, the MMP series is incomplete. Therefore, the price of Maya petroleum is used in place of MMP in order to obtain a complete data series consistent with the corresponding 192 observations:

$$
\mathrm{FPT}=\alpha+\beta_{1} \mathrm{MAYA}+\beta_{2} \mathrm{GS}+\beta_{3} \mathrm{IPI}+\varepsilon .
$$

Where Maya represents the international price of this type of petroleum.

Congress in Mexico forecasts oil prices in December as part of the budgeting process for the following year; sometimes the forecasted price is lower than the actual price. This creates unexpected oil revenues that should have an impact on taxation. This is why another specification substitutes Maya in Eq. (4) with unexpected oil revenues (UOR):

$$
\mathrm{FPT}=\alpha+\beta_{1} \mathrm{UOR}+\beta_{2} \mathrm{GS}+\beta_{3} \mathrm{IPI}+\varepsilon .
$$

This number is calculated by subtracting the forecasted oil price from the actual oil price (MMP). That difference is then multiplied by the total number of oil exports, resulting in UOR. 
Table 3

Summary statistics

\begin{tabular}{|c|c|c|c|c|}
\hline Variable & Mean & Max. & Min. & \# of Obs. \\
\hline Fiscal Policy Taxation (FPT) & $441.47(95.01)$ & 754.482 & 270.659 & 192 \\
\hline Oil-Related Revenues (ORR) & $333.56(88.89)$ & 710.002 & 191.134 & 192 \\
\hline Government Spending (GS) & $750.95(275.88)$ & 2174.636 & 431.257 & 192 \\
\hline Unexpected Oil Revenues (UOR) & $40.629(41.063)$ & 141.195 & -55.075 & 93 \\
\hline Industrial Production (IPI) & $117.24(17.09)$ & 144.30 & 89.20 & 192 \\
\hline Mexican Mixture Price (MMP) & $24.65(9.77)$ & 51.38 & 7.68 & 93 \\
\hline Maya Petroleum Price (MAYA) & $18.09(8.05)$ & 47.73 & 6.37 & 192 \\
\hline
\end{tabular}

Notes: Standard Deviations are in parentheses. FPT, ORR, GS, and UOR are in hundred million of pesos. MMP and MAYA are in US Dollars.

This amount is in U.S. dollars but is converted into pesos using the average monthly exchange rate. This regression consists of only 92 observations because of the lack of data for MMP.

An Autoregressive Integrated Moving Average (ARIMA) specification (Box and Jenkins, 1976) is used to estimate Eqs. (3)-(5). The observations described above are assumed to be taken from a sample of equally distributed intervals, a standard assumption in ARIMA and other timeseries models (Wooldrigde, 1992). The specification uses previous movements of the explanatory variables to explain and predict future variations of the dependent variable, in this case fiscal policy taxation (FPT) (Pindyck and Rubinfeld, 1998).

There are two approaches for ARIMA model estimation: the Traditional Transfer Function (TTF) and the Linear Transfer Function (LTF). The identification procedure is the main difference between these two techniques. The Traditional approach first estimates the univariate ARIMA equations for the dependent and independent variables. The Linear Transform Function first looks at the potential correlations between the independent variable series and the explanatory variables (Coronado et al., 2004).

The LTF approach has been successfully employed in studies on energy consumption. Tzerkezos (1992) uses the LTF technique to analyze and forecast electricity consumption in Greece. Also, Liu and Lin (1991) employ the same procedure to examine and predict residential consumption of natural gas in Taiwan. This technique is ideal for energy data collected on a monthly basis, such as those used in this study. ${ }^{12}$

\section{Empirical results}

Table 3 shows summary statistics for the variables of interest including maxima, minima, and number of observations. The variance in the level of government spending is higher than for fiscal policy taxation (FPT) and oil-related revenues (ORR). Relative to that of FPT and ORR, the standard deviation for unexpected oil revenues (UOR) is considerably high. True to its name, UOR takes on a wide range of values including negative ones, precisely because of unexpected changes in the petroleum market.

\footnotetext{
${ }^{12}$ The authors thank Thomas M. Fullerton, Jr. for pointing out the relevance of Linear Transfer Function (LTF) specifications for this study, as well as pointing out the examples in the literature cited above.
} 
Table 4

Effect of Oil-related revenues and other variables on taxation

\begin{tabular}{|c|c|c|c|}
\hline \multicolumn{2}{|l|}{ Variable } & \multicolumn{2}{|l|}{ Coefficient } \\
\hline Constant & & $-1.1608(0.6028)$ & \\
\hline ORRD(-2) & & $-0.2661(0.0933)$ & \\
\hline $\operatorname{GSD}(-3)$ & & $0.0855(0.0290)$ & \\
\hline $\operatorname{GSD}(-4)$ & & $0.1093(0.0219)$ & \\
\hline GSD(-25) & & $0.2113(0.0204)$ & \\
\hline IPID(-36) & & $4.8752(1.2691)$ & \\
\hline $\operatorname{AR}(7)$ & & $-0.1725(0.0732)$ & \\
\hline $\operatorname{AR}(12)$ & & $0.4597(0.1015)$ & \\
\hline MA(1) & & $-0.8387(0.0424)$ & \\
\hline $\operatorname{MA}(27)$ & & $-0.2303(0.0477)$ & \\
\hline Number of Observations & 191 & Mean dependent var. & 0.4841 \\
\hline$R^{2}$ & 0.8648 & S.D. dependent var. & 101.1807 \\
\hline Adjusted $R$ & 0.8556 & $F$-statistic & 94.5061 \\
\hline Durbin-Watson & 2.0932 & & \\
\hline
\end{tabular}

Notes. Dependent Variable is FPTD and sample period is from January 1990 to December 2005. Estimation procedure consists of Linear Transfer Function.

$\mathrm{AR}(X)$ refers to autoregressive term lagged $\times$ periods. $\mathrm{MA}(X)$ refers to moving average term lagged $\times$ periods. Standard errors in parentheses.

A correlogram test on Eq. (3) reveals that only GS is stationary. The other three variables are first-order non-stationary. A First Difference Transformation solves this problem:

$$
\mathrm{FPTD}=\alpha+\beta_{1} \mathrm{ORRD}+\beta_{2} \mathrm{GSD}+\beta_{3} \mathrm{IPID}+\varepsilon .
$$

Where FPTD, ORRD, GSD and IPID simply represent the stationary version of FPT, ORR, GS and IPI. A similar transformation is applied to Eqs. (4) and (5):

$$
\begin{aligned}
& \text { FPTD }=\alpha+\beta_{1} \text { MAYAD }+\beta_{2} \mathrm{GSD}+\beta_{3} \mathrm{IPID}+\varepsilon . \\
& \mathrm{FPTD}=\alpha+\beta_{1} \mathrm{UORD}+\beta_{2} \mathrm{GSD}+\beta_{3} \mathrm{IPID}+\varepsilon .
\end{aligned}
$$

Where MAYAD and UORD represent stationary versions of MAYA and UOR respectively.

In order to proceed with the Linear Transfer Function, potential correlations between the dependent and each independent variable are evaluated using the cross-correlogram test. The results provide a potential lag structure for the variables. Regressions are run until the statistical significance for variables and their lags is optimal. Once this is done, it is necessary to find the lag structure of the dependent variable through Auto Regressive and Moving Average (ARMA) estimation. Before testing the model, it is necessary to attain statistical significance in the explanatory variables, their lags, and the ARMA terms ${ }^{13}$. It is also desirable to maximize $R^{2}$.

The regression results are shown in Tables 4-6. All of the regressions have relatively high $R^{2}$ and Adjusted $R^{2}$ showing that the explanatory variables and their lags explain over $80 \%$ of the variance in fiscal policy taxation. The dependent variable's lag structure does not follow a clear pattern; the ARMA terms employed simply prevent any possible autocorrelation with fiscal policy taxation.

\footnotetext{
${ }^{13}$ The AR (7) term in Regressions (3') and (5') as well as the AR (3) term in Regression (4') are included in order to reduce serial autocorrelation. We thank an anonymous referee and Roberto Tinajero for pointing this out.
} 
Table 5

Effect of Maya petroleum price and other variables on taxation

\begin{tabular}{|c|c|c|c|}
\hline \multicolumn{2}{|l|}{ Variable } & \multicolumn{2}{|l|}{ Coefficient } \\
\hline Constant & & $-1.2715(0.9717)$ & \\
\hline MayaD(-6) & & $-2.9631(1.3094)$ & \\
\hline GSD(-3) & & $0.0679(0.0312)$ & \\
\hline GSD(-16) & & $0.1111(0.0205)$ & \\
\hline GSD(-25) & & $0.1695(0.0217)$ & \\
\hline IPID(-36) & & $4.6072(1.5170)$ & \\
\hline $\operatorname{AR}(3)$ & & $0.1604(0.0942)$ & \\
\hline $\operatorname{AR}(12)$ & & $0.5158(0.1124)$ & \\
\hline MA(1) & & $-0.7711(0.0521)$ & \\
\hline MA(27) & & $-0.3323(0.0735)$ & \\
\hline Number of Observations & 191 & Mean dependent var. & 0.4842 \\
\hline$R^{2}$ & 0.8554 & S.D. dependent var. & 101.1807 \\
\hline Adjusted $R$ & 0.8456 & $F$-statistic & 87.4646 \\
\hline Durbin-Watson & 2.1309 & & \\
\hline
\end{tabular}

Notes. Dependent Variable is FPTD and sample period is from January 1990 to December 2005. Estimation procedure consists of Linear Transfer Function.

$\mathrm{AR}(\mathrm{X})$ refers to autoregressive term lagged $\times$ periods. $\mathrm{MA}(\mathrm{X})$ refers to moving average term lagged $\times$ periods. Standard errors in parentheses.

Tables 4 and 5 show that government spending has a positive, progressive, and statistically significant effect on fiscal policy taxation. As time goes by, the positive coefficient on GSD increases in magnitude. This seems to be an ad hoc effect; in other words, spending changes according to the government's needs, consistent with the spend-tax hypothesis.

In all three specifications, the Industrial Production Index has the strongest effect on fiscal policy taxation. The magnitude of the coefficient is the highest of all the coefficients in the regression and is statistically significant at $1 \%$ in the first two regressions $(5 \%$ in the

Table 6

Effect of unexpected oil revenues and other variables on taxation.

\begin{tabular}{|c|c|c|c|}
\hline \multicolumn{2}{|l|}{ Variable } & \multicolumn{2}{|l|}{ Coefficient } \\
\hline Constant & & $-2.4237(5.5306)$ & \\
\hline UORD(-5) & & $-0.9951(0.2755)$ & \\
\hline GSD(-1) & & $0.2141(0.0288)$ & \\
\hline GSD $(-3)$ & & $0.0818(0.0325)$ & \\
\hline GSD(-16) & & $0.1474(0.0202)$ & \\
\hline $\operatorname{IPID}(-36)$ & & $8.7300(3.5853)$ & \\
\hline $\operatorname{AR}(7)$ & & $-0.2347(0.1121)$ & \\
\hline $\operatorname{AR}(9)$ & & $0.2779(0.1350)$ & \\
\hline MA(1) & & $-0.5914(0.1065)$ & \\
\hline MA(12) & & $-0.4323(5.1600)$ & \\
\hline Number of observations & 92 & Mean dependent var. & 2.1660 \\
\hline$R^{2}$ & 0.8502 & S.D. dependent var. & 117.5421 \\
\hline Adjusted $R$ & 0.8301 & $F$-statistic & 42.2527 \\
\hline Durbin-Watson & 2.234 & & \\
\hline
\end{tabular}

Notes. Dependent Variable is FPTD and sample period is from April 1998 to December 2005. Estimation procedure consists of Linear Transfer Function.

$\mathrm{AR}(\mathrm{X})$ refers to autoregressive term lagged $\times$ periods. $\mathrm{MA}(\mathrm{X})$ refers to moving average term lagged $\times$ periods. Standard errors in parentheses. 
third regression). Interestingly enough, the lag structure indicates that the effect takes 3 years (36 months) to appear.

The estimated coefficient of the variable of interest (ORRD, MAYA, and UORD) is negative and statistically significant. No matter how it is measured, oil revenues are inversely related to tax collection in Mexico. The results are puzzling at first: When oil revenues increase, tax revenues decrease. This reduction in government revenue from taxes may be hard to interpret in real life. For Mexico, it might be a significant decrease in enforcement actions, as well as lower auditing and monitoring efforts that, after several months, show up as a negative impact on government tax revenues.

\section{Discussion}

The estimated coefficient for the Industrial Production Index implies a 3-year lag effect. An improvement in the index, via the enhancement of one or more sectors, would increase fiscal income only after 36 months. Mexican politicians may not care as much about actual improvements in the economy. The electoral cycle in Mexico is from 3 to 6 years; therefore, an increase in non-oil tax revenues from an improvement in industrial production may show up after politicians leave office.

Oil-related revenues provide politicians with a way to expand the government's budget in the short run. Fluctuations in the price of oil, as well as unexpected oil revenues, impact non-oil taxation rapidly. This explains why the federal government relies so much on taxing PEMEX and why it has no incentive to relieve PEMEX's tax burden. The results in this study imply a substitution effect between oil duties and tax revenues, consistent with Tijerina-Guajardo and Pagán (2003).

PEMEX does not benefit from high prices of oil. These prices and the resulting oil-related inflows represent a way to get around the problems of tax evasion and inefficient tax collection for the Mexican government. In 1978, when the giant oilfields were discovered, the federal government began a dependence on petroleum that persists to this day.

The observed relationship between unexpected oil revenues and fiscal policy taxation should be examined with caution. The regression consists of 92 observations; despite this, one is able to reach one preliminary conclusion: Unexpected windfalls from petroleum exports may considerably influence the taxation process, leading to a decrease in efforts to collect taxes efficiently and enforce tax laws.

Mexico's fiscal policy is thus a function of circumstances not entirely under its control. In 2005 , oil-related revenues accounted for $37.2 \%$ of total fiscal revenues, and this percentage may be an increasing trend due to rising international oil prices. The portion of the budget from oilrelated revenues is contributing to the reduction of non-oil-related ones. If the projection of exhaustion of oil reserves by 2016 is accurate, Mexico has less than 10 years to reverse this trend.

The results reached in the present study confirm the importance of changing current tax and oil-related policies for Mexico. Proven reserves are being consumed at an accelerated pace, adding a time constraint. Thus, actions must be taken as soon as possible.

According to its World Economic Outlook of April 2006, the International Monetary Fund (IMF) states that Mexico should put a rule in place for the allocation of unexpected oil revenues, similar to Devlin and Titman (2004). It also recommends diversifying the tax base in order to reduce dependence on high prices for oil (International Monetary Fund [IMF], 2006). If implemented, both of these recommendations could be highly beneficial to PEMEX and Mexico.

Actions to reduce dependence on oil-related tax revenues should be taken. First, the government should tax PEMEX's profits, not gross revenues. Second, the government should decrease taxes charged to PEMEX to about $35 \%$ on all profits (expected and unexpected), like any other company 
in Mexico. This would allow PEMEX to actually generate profits and be able to invest in high technology. Developing new oil facilities would preserve Mexico's position as an oil exporter longer than current expectations.

Proven reserves are being exhausted, and in order to find new reserves, investments in technology must be made quickly. One way to do so is to allow foreign co-investment in petroleum exploration. A reduction in the dependence of oil-related contributions would make PEMEX a more attractive investment partner precisely because it would generate substantial profits.

If the changes above take place, a portion of government revenues would be substantially reduced. However, the real gain is the transformation of the petroleum industry from a source of fiscal revenue (and foreign exchange) to a genuine engine of economic growth.

\section{References}

Auty, R.M., 2001. The political economy of resource-driven growth. European Economic Review 45 (4-6), 839-846. Baghestani, H., McNown, R., 1994. Do revenues respond to budgetary disequilibria? Southern Economic Journal 61 (2), $311-323$.

Barro, R.J., 1979. On the determination of public debt. Journal of Political Economy 87 (5), 940-971.

Box, G., Jenkins, G., 1976. Time Series Analysis, Control, and Forecasting. Holden-Day, San Francisco.

Boye, F., 2002. Oil and macroeconomic fluctuations in Mexico. OPEC Review: Energy Economics and Related Issues 26 (4), 309-327.

Chalk, N., 1998. Fiscal sustainability with non-renewable resources. IMF Working Paper.

Coronado, R., Fullerton, T.M., Clark, D.P., 2004. Short-run maquiladora employment dynamics in Tijuana. Annals of Regional Science 38, 751-763.

Crandall, R., Paz, G., Roett, R., 2005. Mexico's Democracy at Work. Lynne Rienner Publishers, United States.

Devlin, J., Titman, S., 2004. Managing oil price risk in developing countries. World Bank Observer 19 (1), $119-139$.

Doppelhofer, G., Miller, R.I., Sala-i-Martin, X., 2004. Determinants of long-term growth: a Bayesian Averaging of Classical Estimates (BACE) approach. American Economic Review 94 (4), 813-835.

Everhart, S., Duval-Hernandez, R., 2001. Management of oil windfalls in Mexico: historical experience and policy options for the future. The World Bank, Policy Research Working Paper, 2592, pp. 1-32.

Friedman, M., 1978. Limitations of tax limitations. Policy Review 5 (78), 7-14.

Gelb, A.H., 1988. Oil windfalls: blessing or curse? Oxford University Press, Oxford.

Gylfason, T., 2001. Natural resources, education, and economic growth. European Economic Review 45 (4-6), 847-859.

Hamilton, K., 2001. Sustainability of extractive economies. In: Auty, R.M. (Ed.), Resource Abundance and Economic Development. Oxford University Press, New York, pp. 36-56.

Hausmann, R., Rigobon, R., 2002. An alternative theory of the resource curse. In: Davis, J.M., Ossowski, R., Fedelino, A. (Eds.), Fiscal Policy Formulation and Implementation in Oil-producing Countries. International Monetary Fund, pp. $13-44$. 2003.

Heroico Congreso de la Unión, 2006. Código Fiscal de la Federación. http://www.diputados.gob.mx/LeyesBiblio/pdf/8.pdf.

Heroico Congreso de la Unión, 2005. Ley de Ingresos de la Federación para el Ejercicio Fiscal de 2005. http://www. diputados.gob.mx/LeyesBiblio/abro/LIF05_abro.pdf.

Instituto Mexicano del Petroleo [IMP], 2006. www.imp.mx/.

Instituto Nacional de Estadistica Geografia e Informatica [INEGI], 2006. www.inegi.gob.mx/.

International Monetary Fund [IMF], 2006. World Economic Outlook, April 2006: Globalization and Inflation. International Monetary Fund, Washington, DC.

Karl, T.L., 1999. The perils of the petro-state: reflections on the paradox of plenty. Journal of International Affairs 53 (1), 31-48.

Kronenberg, T., 2004. The curse of natural resources in the transition economies. Economics of Transition 12 (3), 399-426.

Lewin, M., Devlin, J., 2002. Issues in oil revenue management. ESMAP Workshop on Petroleum Revenue Management. World Bank, Washington, DC.

Liu, L., Lin, M., 1991. Forecasting residential consumption of natural gas using monthly and quarterly time series. International Journal of Forecasting 7, 3-16.

Lustig, N., 1998. Mexico: The Remaking of an Economy. The Brookings Institution, Washington, DC.

Morales, I., Escalante, C., Vargas, R., 1988. La formacion de la política petrolera en México, 1970-1986. El Colegio de Mexico, Mexico, DF. 
Padilla, C., (Executive Producer). El Cristal con que se mira con Víctor Trujillo. [Television Broadcast.] Televise canal 4: Mexico City, DF; 2005.

Peacock, A., Wiseman, J., 1979. Approaches to the analysis of government expenditures growth. Public Finance Quarterly $7(1), 3-23$.

Pindyck, R.S., Rubinfeld, D.L., 1998. Econometric models and econometric forecast. Irwin/McGraw-Hill, United States of America.

Roy, A.G., Van den Berg, H., 2000. Are petroleum exports an engine for growth? Time-series evidence for five oil exporters. Journal of Energy and Development 26 (1), 55-69.

Sachs, J.D., Warner, A.M., 1995. Natural resource abundance and economic growth. National Bureau of Economic Research, Working Paper No. 5398: Cambridge MA.

Sachs, J.D., Warner, A.M., 2001. The curse of natural resources. European Economic Review 45 (4-6), 827-838.

Sala-i-Martin, X., 1997. I just ran two million regressions. American Economic Review 87 (2), 178-183.

Secretaría de Energía de Mexico [SENER], 2004. www.sener.gob.mx.

Secretaría de Hacienda y Crédito Público de México [SHCP], 2006. www.shcp.gob.mx/index.html.

Servicio de Administración Tributaria [SAT], 2005. www.sat.gob.mx/sitio_internet/informacion_fiscal/legislacion/52_3369. $\mathrm{html} /$.

Shields, D., 2003. PEMEX: un futuro incierto. Editorial Planeta Mexicana, S.A.de C.V.: Mexico, DF.

Sistema de Información Energética [SIE], 2006. sie.energia.gob.mx/sie/bdiController?action=login.

Street, J.H., 1985. Development planning and the public enterprise: the case of Pemex. Journal of Interamerican Studies and World Affairs 27 (4), 141-154.

Tijerina-Guajardo, J.A., Pagán, J.A., 2003. Government spending, taxation, and oil revenues in Mexico. Review of Development Economics 7 (1), 152-164.

Tzerkezos, E.D., 1992. Forecasting residential electricity consumption in Greece using monthly and quarterly data. Energy Economics 14, 226-232.

Wooldrigde, J.M., 1992. Introductory Econometrics; A Modern Approach. South Western College Publishing, United States of America. 